\title{
Discussion on Practical Teaching Reform of Higher Vocational Colleges
}

\author{
Yinquan Hu, Xiaobing Wu \\ Chongqing Vocational Institute of Engineering, Chongqing, 402260, China
}

\author{
Keywords: Higher vocational college, Practical teaching, Reform
}

\begin{abstract}
Higher vocational college is an important base of cultivating practical talents. But since practical teaching method of higher vocational college falls behind, colleges cannot train practical talents in quantity. Thus, it is very necessary to reform practical teaching in higher vocational colleges. Practical teaching plays a decisive role in higher vocational colleges, and it is the core of teaching. Because practical teaching fails to advance with the times, teaching contents fail to keep up with the pace of times. Thus, practical teaching of higher vocational colleges does not comply with social needs and cannot cultivate the talents needed by society. To improve such situation, higher vocational colleges reform practical teaching. This paper deeply analyzes the reform, sets forth the views and hopes to provide help for higher vocational colleges to better carry out practical teaching reform.
\end{abstract}

\section{Introduction}

As new curriculum standard is issued, traditional practical teaching mode of higher vocational colleges cannot meet social demand. Obsolete teaching mode is gradually eliminated by society. In the face of such situation, it is imperative for higher vocational colleges to reform practical teaching.

\section{Necessity of reforming practical teaching of higher vocational colleges}

\section{Practical teaching reform is an effective approach to train applied talents}

Teaching characteristic of higher vocational colleges is practical teaching. Practical teaching is the core of education. The main purpose of practical teaching is to provide effective ways for cultivating applied talents so as to meet social demand for talents. Practical teaching can meet the need of combining social practice, teaching and labor and provide ways for unifying social practice, theory learning and practical teaching. Thus, practical teaching reform of higher vocation colleges complies with social development trend and advances with the times. Higher vocation colleges may adopt college-enterprise cooperation and substituted post practice in the process of practical teaching reform. In the reform stage, the teaching mode which combines practice and theory should be adhered to so as to further cultivate students' practical ability and achieve the purpose of cultivating practical talents $^{[1]}$. When higher vocation colleges reform practical teaching, it is required to confirm development ways, take the way of connotation development, enhance practical teaching management, establish sound operation mechanism, and make it more standard and institutional so as to make sure students cultivated by higher vocation colleges integrate favorable ideology, morality and practical work ability and to make contributions to social development.

Practical teaching reform is the need of deepening college-enterprise cooperation and improving talent training quality

In traditional practical teaching, higher vocational colleges reach an agreement with enterprises to jointly train practical talents in order to better carry out practical teaching. College-enterprise cooperation mode has positive significance for training practical talents. However, some problems still exist in actual execution process. These problems cause college-enterprise cooperation mode cannot be fully exerted and result in adverse impacts on training practical talents. In view of such situation, higher vocational colleges should deepen college-enterprise cooperation, solve problems existing in cooperation, give full play to the function of college-enterprise cooperation and boost the quality of training practical talents in the process of reforming practical teaching. The main problem 
existing in actual operation of college-enterprise cooperation is that colleges should pay attention to college-enterprise cooperation, while enterprises do not have high enthusiasm for this. The main cause for such problem is that enterprises fail to gain the strong support of government in college-enterprise cooperation and lack interest-driving. Thus, enterprises have no high enthusiasm for cooperative school running of higher vocational colleges. Higher vocational colleges carry out teaching with college-enterprise cooperation mode which has problems, which will cause talents cultivated by colleges and enterprises' actual demand have differences. Hence, higher vocational colleges should enhance cooperation with enterprises in the process of practical teaching reform, gain more convenience for teaching through enhancing correlation, make substituted post practice conducted effectively so as to improve the quality of talents trained by higher vocational colleges in practical teaching.

\section{Practical teaching reform principles of higher vocational college}

With continuous development of society, social demand for talents has obvious changes. Higher vocational colleges carry out deep reform for practical teaching in order to meet social demand for talents. In the reform process, the following principles should be followed: firstly, higher vocation colleges should pay attention to choosing teaching site for practical teaching. Practical teaching should not excessively depend on indoor teaching, but should set up the laboratory on the site of laboratory. In this way, teachers may explain knowledge for students in the specific construction so as to improve their knowledge mastery degree. Secondly, before carrying out teaching, teachers should formulate teaching scheme and must make sure the scheme is scientific and reasonable. Meanwhile, corporate demand for talents should be blended in teaching program to achieve the balance between supply and demand of teaching and market. Thirdly, in practical teaching, teachers should take effective measures to reduce the difficulty of difficult problems and establish perfect practical teaching system. In this way, teachers can effectively carry out teaching and help students grasp practical ability. Fourthly, in the process of practical teaching reform, higher vocational colleges should reserve sufficient space during formulating teaching scheme. When the market alters, colleges may supplement or change practical teaching according to changes. Besides, higher vocational colleges should give the right to use the space to teachers and students so as to encourage teachers and students to actively cope with market changes ${ }^{[2]}$. Fifthly, with continuous development of society, the requirements for talents also become higher and higher. Thus, higher vocation colleges are required to cultivate students from technical and non-technical perspectives under the background of market economy. Non-technology includes communication, economy, law ad practical skills. Only when teachers carry out teaching from the two aspects can cultivate qualified talents. Sixthly, practical teaching has certain difficulties. If teachers adopt single teaching means for teaching, good teaching effect cannot be gained. So, higher vocation colleges should establish multiple ways to make sure the teaching content is real and to reflect new situation and new achievements of teaching in the process of practical teaching reform.

\section{Form and feature of teaching of higher vocational colleges}

\section{Form of teaching of higher vocational colleges}

Practical teaching means teachers should combine relevant practical work, let students carry out practical work under the guidance of theoretical knowledge and finally help students grasp practical work ability on the basis of learning theoretical knowledge. The higher vocational college is a main base of training practical talents. Its teaching objective decides teaching form. Practical teaching forms of higher vocational colleges include the following. Firstly, carry out simulation exercise and various experiments by taking classroom as the platform; secondly, combine theoretical knowledge for electromechanical operation; thirdly, carry out all kinds of skill training; fourthly, carry out comprehensive teaching; fifthly, carry out all kinds of social practice activities beyond teaching 
program. Although the reform forms are different, the service objects are consistent. Practical teaching of higher vocational colleges aims to train the talents needed by the society.

\section{Features of practical teaching of higher vocational colleges}

Features of practical teaching of higher vocational colleges mainly include the following: firstly, vocational teaching feature. Higher vocational colleges should not just start from occupational quality, but also should pay attention to technology, intelligent structure and practical application ability during training students. Only when various aspects satisfy social demand can teaching of higher vocational colleges be successful. This is vocational teaching features owned by practical teaching. Secondly, technology application feature. Practical teaching course of higher vocational colleges must be a teaching system which combines professional technology application ability and professional skills. The objective of this teaching system is to train students' ability to solve problems and apply technology. Thirdly, modernization feature. In recent years, China's scientific and technological level has kept improving, the application of high and new technologies in enterprises becomes more and more extensive. Thus, corporate demand for talents is on the rise, and the requirements for practical talents gradually improve. In the face of such situation, practical teaching must advance with the times and effectively combine occupational qualities and post skills so as to meet social demand, this is the modernization feature of practical teaching of higher vocational colleges. Fourthly, social practice. The purpose of practical teaching is to train talents for society. This aim decides practical teaching should own social practice feature. Fifthly, college-enterprise cooperation feature $^{[3]}$. To cultivate talents needed by enterprises, practical teaching should specify corporate needs. To better carry out practical teaching, higher vocational colleges combine with enterprises to train practical talents in order to better carry out practical teaching. Such mode can help higher vocational colleges improve teaching level, train more excellent practical talents and solve talent shortage problem so as to achieve win-win.

\section{Effective measures to practical teaching reform of higher vocational colleges}

\section{Achieve "four changes" in teaching form}

Higher vocational colleges must achieve "four changes" in teaching form in order to enhance practical teaching level and offer talents for society. This paper specifically analyzes "four changes" in teaching form. The contents are as follows: firstly, simulation-based practical teaching mode changes to practice-based practical teaching mode. In traditional practical teaching, teachers usually ask students to carry out simulation experiment according to textbook contents so as to let students further master theoretical knowledge. Although such teaching mode has certain effect, it is not obvious. Hence, teachers should perfect it on the basis of simulation-based practical teaching mode and make it evolve to practice-based practical teaching mode. Practice-based practical teaching mode aims to extract materials in reality, combine topics and market and achieve better training of applied talents based on complying with course and graduation design requirements. Secondly, transit to independent type from restrictive type. In traditional graduation design, teachers propose topics and then students study the topics. Such way seriously impacts students' thinking and is adverse to their development. In the face of such condition, teachers should adopt innovation methods in graduation design and let students independently choose topics and teachers so as to motivate their imagination and creativity ${ }^{[4]}$. Thirdly, transit to creation type from verification type. The objective of verification-based teaching is to verify known conditions, while the purpose of creation-based teaching is to explore "unknown things". Higher vocational teaching should regard cultivation of innovative talents as the teaching objective and continuously improve attention to innovation-based teaching. On in this way, talents can be trained in a better way. Fourthly, transform to comprehensive type form single type. When higher vocational colleges carry out practical teaching, they should transform to comprehensive teaching mode, increase teaching contents and expand students' scope of knowledge so as to cultivate comprehensive talents. 


\section{Achieve "three levels" change in teaching program}

When higher vocational colleges carry out practical teaching reform, they should achieve "three levels" change in teaching program. The three levels include basic practice, social practice and professional practice. To achieve change of teaching level, it is required to design teaching contents based on the three levels to better cultivate students' practical ability. Basic practice level refers to experimental lesson, social survey and labor class. Basic practice can train students' basic abilities. Social practice level requires students to enter enterprise and participate in practical production, operation and management activities so as to train their comprehensive practical ability. Professional practice level contains the following contents: graduation paper design and professional survey. Such teaching can train students' professional knowledge application ability and boost students' professional skills.

\section{Apply modern technology in reforming teaching}

Higher vocational colleges should apply modern technology, fuse theoretical knowledge and field teaching and apply cases extensively in practical teaching reform so as to drive application of modern technology in practical teaching. The application of modern technology in teaching reform can adopt quality control method of "folder" type. This paper analyzes this method in detail as follows; before carrying out teaching, teachers should establish student folder and then conduct "trinity" assessment for students. "Trinity" assessment refers to all-round evaluation of students' performance and academic result in a stage by teachers, students and other persons. Such evaluation method can not just objectively estimate students and reflect shortcomings of students in a period, but also cultivate students' self-evaluation ability and lay a favorable foundation for students' all-round development ${ }^{[5]}$.

\section{Conclusions}

In one word, practical teaching reform of higher vocational colleges is of great significance. In the reform process, corresponding principles should be followed. Meanwhile, it is required to combine social demand for talents, continuously liberate thought, and pinpoint the entry point of reform so as to better carry out practical teaching, explore effective ways of practical teaching and lay a good foundation for higher vocational colleges to cultivate more practical talents.

\section{Acknowledgments}

This paper is a part of teaching reform research project of Chongqing Higher Education, Which name is Exploration and Realization of Practical Teaching Reform in Higher Vocational Colleges (JG142012) , and anther project is technical research project of Chongqing Board of Education Committee, which name is Study on Vehicle-Mounted Battery Pack Management System (KJ1503311).

\section{References}

[1] $\mathrm{Xu}$ Enwei, On practical teaching reform of higher vocational colleges. Education Forum, 2013(5):69-70.

[2] Chen Mengzhuo, On practical teaching reform of logistics management major in higher vocational colleges. Journal of Shijiazhuang Institute of Railway Technology, 2010,09(2):126-129.

[3] Zheng Yingmei, Pei Gengsheng, Exploration of tax practical teaching of higher vocational colleges - case study of Hebei Professional College of Political Science and Law. Journal of Liaoning Economic Management Cadre Institute. Journal of Liaoning Economic Vocational Technology Institute, 2014(6):100-102. 
[4] Cao Dan, Discussion on necessity and method of practical teaching reform for computer specialty in higher vocational colleges. China Information Technology Education, 2014(14):11-12.

[5] Wang Wulan, Study on practical teaching reform of Applied Writing course in higher vocational colleges. Curriculum and Educational Studies, 2015(2):252-252. 